\title{
Glutamate Receptors in the Central Nucleus of the Amygdala Mediate Cisplatin-Induced Malaise and Energy Balance Dysregulation through Direct Hindbrain Projections
}

\author{
Amber L. Alhadeff, ${ }^{1}$ - Ruby A. Holland, ${ }^{2}$ Alexandra Nelson, ${ }^{2}$ Harvey J. Grill, ${ }^{1}$ and Bart C. De Jonghe ${ }^{2}$ \\ ${ }^{1}$ Department of Psychology and ${ }^{2}$ Department of Biobehavioral Health Sciences, University of Pennsylvania, Philadelphia, Pennsylvania 19104
}

Cisplatin chemotherapy is used commonly to treat a variety of cancers despite severe side effects such as nausea, vomiting, and anorexia that compromise quality of life and limit treatment adherence. The neural mechanisms mediating these side effects remain elusive despite decades of clinical use. Recent data highlight the dorsal vagal complex (DVC), lateral parabrachial nucleus (IPBN), and central nucleus of the amygdala $(\mathrm{CeA})$ as potential sites of action in mediating the side effects of cisplatin. Here, results from immunohistochemical studies in rats identified a population of cisplatin-activated DVC neurons that project to the IPBN and a population of cisplatinactivated IPBN calcitonin gene-related peptide (CGRP, a marker for glutamatergic neurons in the IPBN) neurons that project to the CeA, outlining a neuroanatomical circuit that is activated by cisplatin. CeA gene expressions of AMPA and NMDA glutamate receptor subunits were markedly increased after cisplatin treatment, suggesting that CeA glutamate receptor signaling plays a role in mediating cisplatin side effects. Consistent with gene expression results, behavioral/pharmacological data showed that CeA AMPA/kainate receptor blockade attenuates cisplatin-induced pica (a proxy for nausea/behavioral malaise in nonvomiting laboratory rodents) and that CeA NMDA receptor blockade attenuates cisplatin-induced anorexia and body weight loss in addition to pica, demonstrating that glutamate receptor signaling in the CeA is critical for the energy balance dysregulation caused by cisplatin treatment. Together, these data highlight a novel circuit and CGRP/glutamatergic mechanism through which cisplatin-induced malaise and energy balance dysregulation are mediated.

Key words: amygdala; anorexia; cisplatin; dorsal vagal complex; glutamate; parabrachial nucleus

\section{Significance Statement}

To treat cancer effectively, patients must follow prescribed chemotherapy treatments without interruption, yet most cancer treatments produce side effects that devastate quality of life (e.g., nausea, vomiting, anorexia, weight loss). Although hundreds of thousands of patients undergo chemotherapies each year, the neural mechanisms mediating their side effects are unknown. The current data outline a neural circuit activated by cisplatin chemotherapy and demonstrate that glutamate signaling in the amygdala, arising from hindbrain projections, is required for the full expression of cisplatin-induced malaise, anorexia, and body weight loss. Together, these data help to characterize the neural circuits and neurotransmitters mediating chemotherapy-induced energy balance dysregulation, which will ultimately provide an opportunity for the development of well tolerated cancer and anti-emetic treatments.

\section{Introduction}

To treat cancer effectively, it is critical that patients adhere to prescribed treatments without interruption or discontinuation.

\footnotetext{
Received Feb. 2, 2015; revised June 25, 2015; accepted June 29, 2015.

Author contributions: A.L.A., H.J.G., and B.C.D.J. designed research; A.L.A., R.A.H., A.N., and B.C.D.J. performed research; A.L.A., A.N., and B.C.D.J. analyzed data; A.L.A., H.J.G., and B.C.D.J. wrote the paper.

This work was supported by the University Research Foundation, University of Pennsylvania, and the National Institutes of Health (Grants NIH-DK21397 and NIH-NSO8463).

The authors declare no competing financial interests.

Correspondence should be addressed to Bart C. De Jonghe, Department of Biobehavioral Health Sciences, University of Pennsylvania, 418 Curie Blvd., Philadelphia, PA 19104. E-mail: bartd@nursing.upenn.edu.

DOI:10.1523/JNEUROSCI.0440-15.2015

Copyright $\odot 2015$ the authors $\quad 0270-6474 / 15 / 3511094-11 \$ 15.00 / 0$
}

Unfortunately, treatments such as cisplatin chemotherapy, a widely used and studied antineoplastic drug (Andrews and Horn, 2006; Percie du Sert et al., 2011), are accompanied by severe side effects such as nausea, vomiting, anorexia, and weight loss (Von Hoff et al., 1979) that devastate quality of life and require constant symptom management. Despite obvious clinical importance, the central circuits and neurochemical mechanisms mediating these side effects of cisplatin are not fully known. A comprehensive understanding of these neural systems will allow for the development of more effective cancer pharmacotherapies with fewer side effects.

Rats are commonly used as models to study food intake control and cisplatin-induced anorexia and malaise (Andrews and 
A

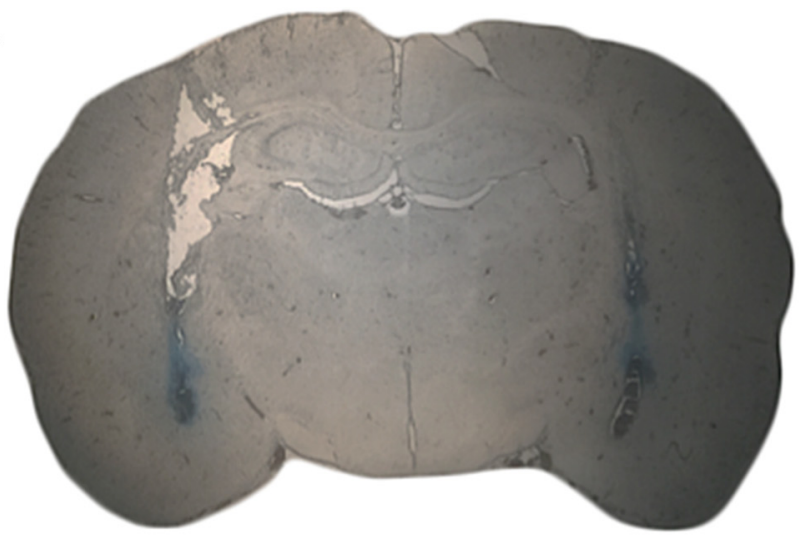

B

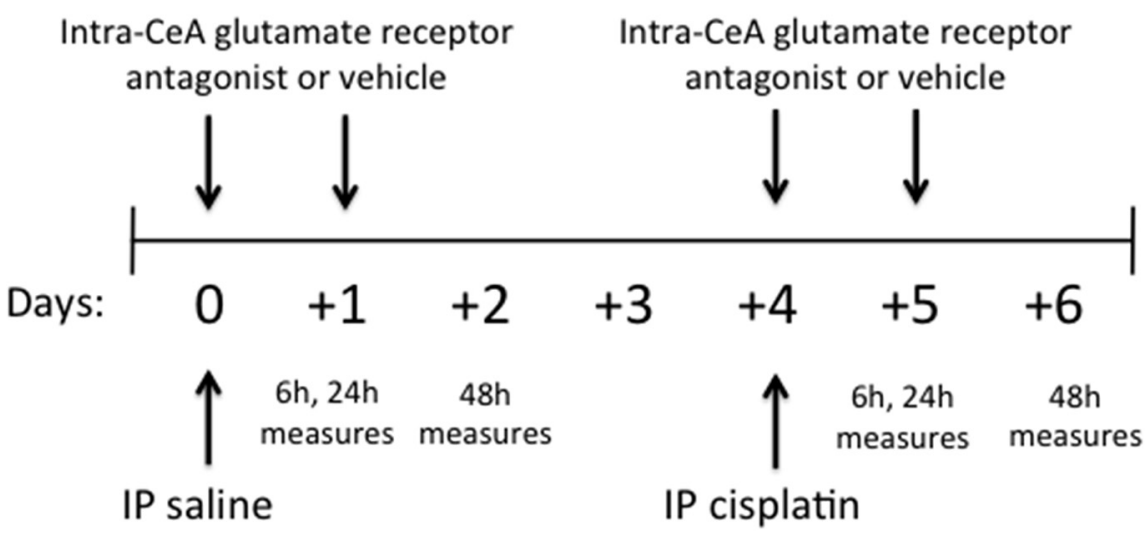

Figure 1. A, Representative image of bilateral cannulae tracks and injection site in CeA used for Experiments 4 and 5. B, Timeline of injections in Experiments 4 and 5.

Horn, 2006). In response to cisplatin and a wide range of other noxious stimuli, rats (which do not vomit) innately display pica, the consumption of nonnutritive kaolin clay, which is thought to be a consequence of nausea and/or visceral malaise (Andrews and Horn, 2006; Andrews and Sanger, 2014). In addition, the pattern of cisplatin-induced neural activation (i.e., cFos immunoreactivity) observed in rats is similar to data from vomiting species (Horn et al., 2007): in the dorsal vagal complex (DVC), including the hindbrain nucleus tractus solitarius (NTS) and area postrema (AP), the lateral parabrachial nucleus (lPBN), and the central nucleus of the amygdala (CeA). The neural circuitry and neurochemical phenotypes of these cisplatin-activated neurons, however, remain unknown.

There is accumulating evidence of a role for glutamate receptor signaling in mediating anorexia and nausea/malaise from cisplatin and other noxious stimuli. We have shown previously that cisplatin upregulates central AMPA and NMDA receptor subunit expression in mice (Holland et al., 2014), highlighting glutamate signaling as a potential mediator of cisplatin's side effects. Furthermore, a recent study has identified a subpopulation of IPBN calcitonin gene-related peptide (CGRP)/glutamate neurons that project to the CeA; when these neurons are activated, food intake is potently suppressed (Carter et al., 2013). Interestingly, these neurons are stimulated by noxious stimuli such as lithium chloride, a powerful emetic that has been shown to increase glutamate release in the amygdala in the context of conditioning a taste avoidance (Miranda et al., 2002). Whether this projection also plays a role in cisplatin-induced malaise is unknown. Therefore, the current experiments test the hypothesis that cisplatin treatment activates $\mathrm{PBBN}$ CGRP/glutamate neurons that project to the $\mathrm{CeA}$, resulting in nausea/malaise, anorexia, and body weight loss.

The studies described here used neuroanatomical tracing and immunohistochemistry (IHC) to elucidate the neural circuitry activated by cisplatin treatment and quantitative PCR to examine changes in AMPA and NMDA subunit gene expression after cisplatin treatment. In addition, behavioral/pharmacological experiments investigated the role of CeA glutamate receptor signaling in mediating cisplatin-induced side effects in a rat model. Data show that CeA NMDA and AMPA/kainate receptor blockade attenuate cisplatin-induced malaise and energy balance dysregulation, likely through a circuit involving the DVC and direct projections from IPBN CGRP/glutamate neurons.

\section{Materials and Methods}

Subjects and drugs. Male Sprague Dawley rats (250-265 g upon arrival; Harlan Laboratories) were individually housed in hanging metal cages in a $12 \mathrm{~h}$ light $/ 12 \mathrm{~h}$ dark cycle. Rats had ad libitum access to pelleted chow (Purina Rodent Chow 5001) and water except when otherwise noted. All procedures conformed to and received approval from the institutional standards of the University of Pennsylvania Animal Care and Use Committee.

Cisplatin (cis-diamineplatinum dichloride; Sigma-Aldrich) was sonicated in saline $(0.15 \mathrm{M} \mathrm{NaCl})$ and vortexed immediately before experiments commenced. The AMPA/kainate receptor antagonist CNQX (Tocris Bioscience) was dissolved in sterile water. The NMDA receptor antagonist MK-801 (Sigma-Aldrich) was dissolved in artificial CSF (aCSF). The monosynaptic retrograde tracer fluorogold (FG; Fluorochrome) was dissolved to $2 \%(\mathrm{w} / \mathrm{v})$ in sterile water.

Surgery. Rats received intramuscular anesthesia (ketamine, $9 \mathrm{mg} / \mathrm{kg}$; Butler Animal Health Supply), xylazine (2.7 mg/kg; Anased), and acepromazine $(0.64 \mathrm{mg} / \mathrm{kg}$; Butler Animal Health Supply) and subcutaneous analgesia (2.0 mg/kg Metacam; Boehringer Ingelheim Vetmedica) for all surgeries.

For behavioral experiments, two unilateral 26-gauge guide cannulae were stereotaxically implanted (bilaterally) in the CeA according to the following coordinates: $\pm 4.3 \mathrm{~mm}$ lateral from midline, $2.4 \mathrm{~mm}$ posterior from bregma, and $6.1 \mathrm{~mm}$ ventral from skull surface, with the injector aimed $2.0 \mathrm{~mm}$ below the end of the guide cannulae. Cannulae placements were histologically confirmed postmortem with an injection of Chicago sky blue ink. Animals with injection sites that were not within the CeA were excluded from the analyses. A representative image of the injection site is depicted in Figure 1.

For anatomical tracing experiments, animals were positioned in a stereotaxic device and a unilateral cannula was placed above the CeA (same coordinates as above) or the IPBN (coordinates: $\pm 2.0 \mathrm{~mm}$ lateral from midline, $0.6 \mathrm{~mm}$ anterior to lambda, and $5.7 \mathrm{~mm}$ ventral from skull surface using a $20^{\circ}$ angle, negative slope in the anterior to posterior 
direction). While under anesthesia and in the stereotaxic device, animals received a unilateral $300 \mathrm{nl}$ injection of FG in the CeA or the $1 \mathrm{PBN}$. Injectors were left in place for $1 \mathrm{~min}$ and then removed. Cannulae were removed from the brain and the head incisions were sutured. Representative images of FG injections directed at the IPBN and CeA are shown in Figures $2 F$ and $4 G$, respectively.

$I H C$. Rats were deeply anesthetized and transcardially perfused with 0.1 m PBS (Boston Bioproducts), pH 7.4, followed by 4\% PFA (Boston Bioproducts). Brains were removed and postfixed in $4 \%$ PFA for $4 \mathrm{~h}$ and then stored in $30 \%$ sucrose until brains no longer floated. Brains were sectioned coronally and collected serially in triplicate at the following approximate coordinates: NTS (bregma $-13.9 \mathrm{~mm}$ ), IPBN (bregma $-9.2 \mathrm{~mm}$ ), and amygdala (bregma $-2.4 \mathrm{~mm}$ ).

IHC was conducted according to previously described procedures (Holland et al., 2014). Briefly, sections were washed with $1 \%$ sodium borohydride, followed by washes with $0.1 \mathrm{M}$ PBS. Brain sections were incubated in $5 \%$ normal donkey serum for $1 \mathrm{~h}$, followed by an overnight $(16 \mathrm{~h})$ incubation with primary antibodies: polyclonal goat anti-Fos primary antibody (1:2000, sc-52G; Santa Cruz Biotechnology) and mouse anti-CGRP primary antibody (1:10,000, ab81887; Abcam). Sections were then washed and incubated with secondary antibodies: donkey anti-goat Alexa Fluor 594 and donkey anti-mouse Alexa Fluor 488 (1:500; Jackson ImmunoResearch Laboratories). FG autofluorescence was detected using a special filter (C-FL UV-2A; Nikon Instruments) on a fluorescence microscope (Nikon 80i).

Brain sections were mounted onto glass slides and coverslipped using Fluorogel (Electron Microscopy Sciences). Immunofluorescing neurons were visualized and quantified using fluorescence microscopy (Nikon 80i, NIS Elements AR 3.0) at $10 \times$ and $20 \times$ magnification. Three sections per rat were quantified at the levels of the DVC (bregma $-13.9 \mathrm{~mm}$ ), IPBN (bregma $-9.2 \mathrm{~mm}$ ), and CeA (bregma -2.4). cFos, FG, and CGRP counts were quantified unilaterally in all experiments because the majority of projections from the NTS to IPBN and from IPBN to CeA were ipsilateral in nature, consistent with previous reports (Norgren, 1978; Alhadeff et al., 2014).

Experiment 1: Assessment of cisplatin-induced cFos in DVC neurons projecting directly to the IPBN. Rats $(n=7)$ were injected with intra-lPBN FG as described above. Three days after FG injections, rats were injected intraperitoneally with $6 \mathrm{mg} / \mathrm{kg}$ cisplatin or saline. The dose of cisplatin used in this experiment and in Experiment 2 was selected on the basis of its induction of cFos expression in the brain regions of interest (Horn et al., 2007; Horn, 2009). To control for possible differences in cFos expression due to differential food intake between the cisplatin and saline groups, animals were food deprived for the $24 \mathrm{~h}$ in between intraperitoneal injection and perfusion. Twenty-four hours after cisplatin/saline injection, animals were perfused and DVC brain sections were processed for IHC for cisplatin-induced cFos and FG as described above. CeA brain sections were also analyzed from $n=10$ animals to determine whether cisplatin-activated $\mathrm{CeA}$ neurons have descending projections to the IPBN.

Experiment 2: Assessment of cisplatin-induced cFos in lPBN CGRP/glutamate neurons projecting directly to the CeA. Rats $(n=9)$ were injected with intra-CeA FG as described above. Three days after FG injections, rats were intraperitoneally injected with $6 \mathrm{mg} / \mathrm{kg}$ cisplatin or saline. As in Experiment 1, rats were food deprived for the $24 \mathrm{~h}$ between intraperitoneal injection and perfusion. Twenty-four hours after cisplatin/saline injection, animals were perfused and $\mathrm{PBN}$ brain sections were processed for IHC for cisplatin-induced cFos, FG, and CGRP as described above. DVC brain sections from rats $(n=7)$ were also analyzed to determine whether cisplatin-activated (cFos-positive) DVC neurons project to the CeA.

Experiment 3: Effects of cisplatin treatment on CeA AMPA and NMDA receptor subunit gene expression. Rats were given intraperitoneal saline $(n=5)$ or $6 \mathrm{mg} / \mathrm{kg}$ cisplatin $(n=7) 6 \mathrm{~h}$ before decapitation. As in Experiments 1 and 2, rats were food deprived for the $24 \mathrm{~h}$ between intraperitoneal injection and euthanasia. Whole brains were collected and flash frozen in isopentane. Bilateral micropunches of the CeA were collected according to previously published methods (Holland et al., 2014); micropunches ( $1.0 \mathrm{~mm}$ diameter) began at $-3.0 \mathrm{~mm}$ from bregma and were $\sim 1.5 \mathrm{~mm}$ long. A second cohort of rats received intraperitoneal saline $(n=5)$ or $6 \mathrm{mg} / \mathrm{kg}$ cisplatin $(n=4) 24 \mathrm{~h}$ before decapitation and underwent identical tissue processing.

For quantitative real-time PCR, total RNA was extracted from micropunches using TRIzol (Invitrogen) and RNeasy (Qiagen). cDNA was synthesized using a High Capacity cDNA Reverse Transcription Kit (Applied Biosystems). TaqMan gene expression kits and PCR reagents (Applied Biosystems) were used to quantify relative mRNA levels of AMPA receptor subunits GluA1 (Gria1; Rn00709588_m1) and GluA2 (Gria2; Rn00568514_m1) and NMDA receptor subunits NR1 (Grin1; Rn01436038_m1), NR2A (Grin2A; Rn00561341_m1), and NR2B (Grin2b; Rn00680474_m1) relative to rat $\beta$-actin (Actb, Rn00667869). Gene primers were chosen based on previous studies suggesting a role for these receptor subunits in mediating malaise (Wu et al., 2013; Holland et al., 2014). Relative mRNA expression was calculated using the comparative Ct method as described previously (Bence et al., 2006; Holland et al., 2014).

Experiments 4 and 5: Effects of intra-CeA AMPA/kainate or NMDA receptor blockade on cisplatin-induced anorexia and pica. Rats $(n=11)$ were habituated to experimental procedures and were given ad libitum access to kaolin pellets (Research Diets) for $4 \mathrm{~d}$ in addition to their standard chow and water. Given that the behavioral effects of an acute dose of cisplatin are long-lasting, making a true within-subjects design confounded by previous exposure to the cisplatin stimulus (De Jonghe and Horn, 2008), we used a pseudo-counterbalanced approach described as follows (see Fig. $1 B$ for timeline for Experiments 4 and 5). On day 1 of Experiment 4, weight-matched rats received bilateral $200 \mathrm{nl}$ injections of the AMPA/kainate receptor antagonist CNQX $(0.3 \mu \mathrm{g}, n=6)$ or sterile water $(n=5)$, followed by intraperitoneal saline. Based on our preliminary dose-response studies (data not shown) and the short-term nature of effects of the glutamate receptor antagonists CNQX and MK-801 (Vezzani et al., 1989) on food intake in other ventricular and intraparenchymal sites (Treece et al., 1998; Covasa et al., 2003; Hettes et al., 2007; Mietlicki-Baase et al., 2013; Mietlicki-Baase et al., 2014), rats received a second injection of CNQX or vehicle $24 \mathrm{~h}$ after intraperitoneal injection. The dose of CNQX (and MK-801 in Experiment 5) used was chosen based on preliminary studies that showed no effect on food intake/body weight as a result of drug treatment at the time points of interest. Food and kaolin intake (both accounting for spillage) were measured at $6 \mathrm{~h}$, $24 \mathrm{~h}$ (day 2), and $48 \mathrm{~h}$ (day 3); water intake was measured at 24 and $48 \mathrm{~h}$ after injection. On day 4 , rats received intra-CeA CNQX $(n=6)$ or sterile water $(n=5)$ (counterbalanced based on previous exposure to CNQX) $30 \mathrm{~min}$ before and $24 \mathrm{~h}$ after intraperitoneal cisplatin $(6 \mathrm{mg} / \mathrm{kg})$, with the same food, kaolin, and water measurements. The dose of cisplatin was chosen based on the literature and previous laboratory studies showing that $6 \mathrm{mg} / \mathrm{kg}$ cisplatin is sufficient to reduce food intake and induce pica (De Jonghe and Horn, 2008). On day 7, animals were euthanized via $\mathrm{CO}_{2}$ asphyxiation and analyzed for CeA cannulae placement. One animal was excluded from Experiment 4 due to incorrect cannula placement.

For Experiment 5, a second cohort of rats $(n=12)$ underwent identical experimental procedures but were injected bilaterally intra-CeA with the NMDA receptor antagonist MK-801 $(0.3 \mu \mathrm{g} / 200 \mathrm{nl})$ rather than CNQX. On day 1 , rats received intra-CeA MK-801 $(n=7)$ or aCSF $(n=$ 5 ) before intraperitoneal saline, with an identical intra-CeA injection on day 2. On day 4 , rats received intra CeA MK-801 $(n=6)$ or aCSF $(n=6)$ (counterbalanced based on previous exposure to MK-801) before intraperitoneal cisplatin, with an identical intra-CeA injection on day 5. Two animals were excluded from Experiment 5 due to incorrect cannula placement and an additional two animals were excluded because one or both CeA cannulae became blocked before or during the course of the experiment.

Statistical analyses. All data are expressed as means \pm SEM. For behavioral experiments, two-way ANOVAs in a $2 \times 2$ between-subjects design were performed to evaluate group differences using intraperitoneal drug treatment (cisplatin/vehicle) and intra-CeA drug treatment (MK801/vehicle or CNQX/vehicle) as main effects for food intake, water intake, kaolin intake, and body weight change. Planned post hoc comparisons were conducted with least significant difference tests when applicable. For IHC and PCR experiments, independent samples two-tailed $t$ tests were used to compare counts or relative gene expressions between injec- 

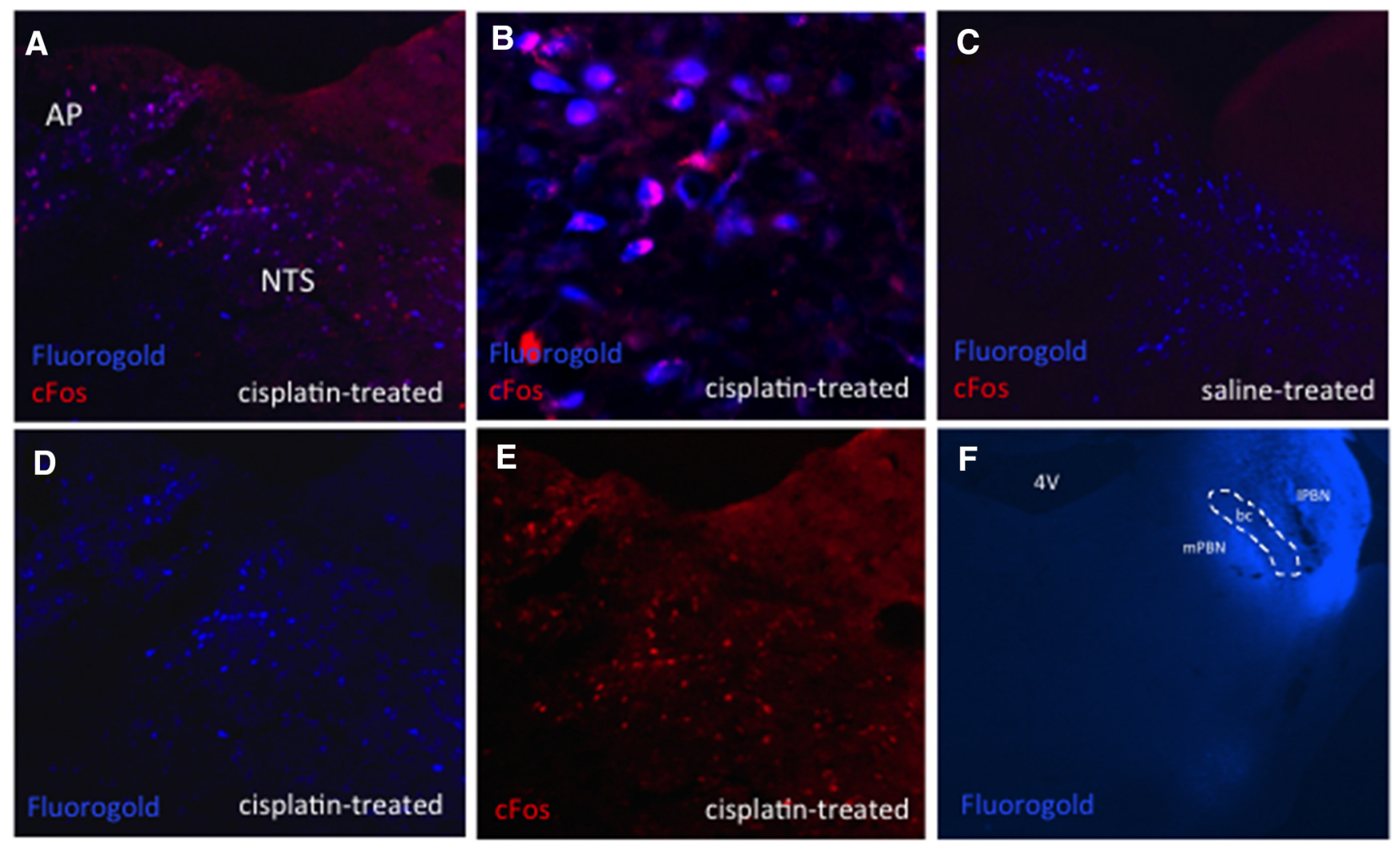

Figure 2. DVC cisplatin-activated neurons project directly to the ipsilateral IPBN. Blue immunofluorescence represents FG-expressing neurons and red immunofluorescence represents cisplatininduced cFos-expressing neurons. $\boldsymbol{A}, \boldsymbol{D}, \boldsymbol{E}$, Representative DVC images from an IPBN FG- and intraperitoneal cisplatin-treated animal. $\boldsymbol{B}$, Representative $20 \times$ DVC image from an IPBN FG- and intraperitoneal cisplatin-treated animal, $\boldsymbol{C}$, Representative DVC image from an IPBN FG- and intraperitoneal saline-treated animal. $\boldsymbol{F}$, Representative IPBN FG injection. $n=4$ cisplatin-treated, $n=$ 3 saline-treated. bc, Brachium conjuntivum; mPBN, medial parabrachial nucleus.

tion conditions (cisplatin vs saline) where appropriate. Statistical differences between mean values were calculated using SAS 9.2 (SAS Institute).

\section{Results}

Experiment 1: Cisplatin-activated DVC neurons project directly to the IPBN

It is well established that DVC neurons are robustly activated by cisplatin (Horn et al., 2007; Horn, 2009). In animals injected with lPBN FG, we observed $11.8 \pm 1.0$ cFos-expressing AP cells per brain section in cisplatin-treated animals (Fig. $2 E$ ) and no cFosexpressing AP cells in saline-treated animals (Fig. 2C). In the NTS, there were $26.6 \pm 1.2$ cFos-expressing cells in cisplatintreated animals (Fig. 2E) and no cFos-expressing cells in salinetreated animals (Fig. 2C). Although there was no detectable cFos immunoreactivity in saline-treated rats, the number of FGexpressing neurons was similar in cisplatin-treated (AP: $30.2 \pm$ 1.3; NTS: $130.6 \pm 2.2$; Fig. $2 D$ ) and saline-treated (AP: $29 \pm 1.8$; NTS: $136.2 \pm 3.4$; Fig. $2 C)$ treated rats $(p=n s)$. We did not observe cisplatin-induced cFos immunoreactivity in the dorsal motor nucleus of the vagus (data not shown), consistent with previous studies in the rat (Horn, 2009). The majority of DVC neurons expressing cisplatin-induced cFos immunoreactivity colocalized with cell bodies positive for FG injected ipsilaterally into the 1 PBN. We observed $82.3 \pm 2.9 \%$ and $81.3 \pm 4.4 \%$ colocalization in the AP and NTS, respectively, in cisplatin-treated animals (see Fig. 2A, $B$ for representative images). There was no colocalization between cFos and FG in saline-treated rats (Fig. 2C).

In animals with $\mathrm{IPBN}$-injected FG, there were $26.5 \pm 1.8 \mathrm{CeA}$ cFos-expressing cells per brain section in cisplatin-treated animals (Fig. 3A) and no cFos expression in the CeA of saline-treated animals (Fig. 3C). There were similar numbers of FG-expressing neurons in cisplatin- and saline-treated groups $(158 \pm 5.4$ cisplatin (Fig. $3 A$ ) versus $156.3 \pm 3.5$ saline (Fig. $3 C)(p=n s)$. CeA neurons activated by cisplatin did not overlap with FG immunofluorescence from IPBN-injected FG animals (Fig. $3 A, B$ ).

A summary of cFos and FG cell counts for each brain region is provided in Table 1 and a summary of the colocalization between cFos- and FG-expressing neurons is provided in Table 2.

\section{Experiment 2: Cisplatin-activated IPBN CGRP/glutamate neurons project directly to the $\mathrm{CeA}$}

In animals injected with CeA FG, we observed $31.4 \pm 1.2$ cFosexpressing $1 \mathrm{PBN}$ cells per brain section in cisplatin-treated animals (Fig. $4 F$ ) and $0.08 \pm 0.08$ cFos-expressing cells in salinetreated animals (Fig. 4C). There were similar numbers of FGexpressing neurons in the cisplatin- and saline-treated groups (119.1 \pm 4.5 cisplatin (Fig. 4D) versus $126 \pm 2.3$ saline (Fig. $4 C$ ) $(p=n s)$ and similar numbers of CGRP-expressing neurons in cisplatin- and saline-treated animals $(39.1 \pm 2.5$ cisplatin-treated; Fig. $4 E$ ) versus $42.9 \pm 3$ saline-treated (Fig. $4 C)(p=n s$ ). Nearly all cisplatin-induced cFos-positive neurons in the ipsilateral IPBN coexpressed CGRP (lPBN: $91.9 \pm 0.34 \%$ ). Furthermore, the majority $(66.5 \pm 8.3 \%)$ of cisplatin-induced cFos neurons colocalized with FG, showing that these neurons project monosynaptically to the CeA. Overall, $57.4 \pm 6.8 \%$ of cisplatininduced cFos neurons colocalized with both FG and CGRP (see Fig. $4 A, B$ for representative images).

In the DVC of animals with CeA-injected FG, there were $12.7 \pm 3.8$ and $27 \pm 7.6$ cFos-expressing neurons per brain sec- 

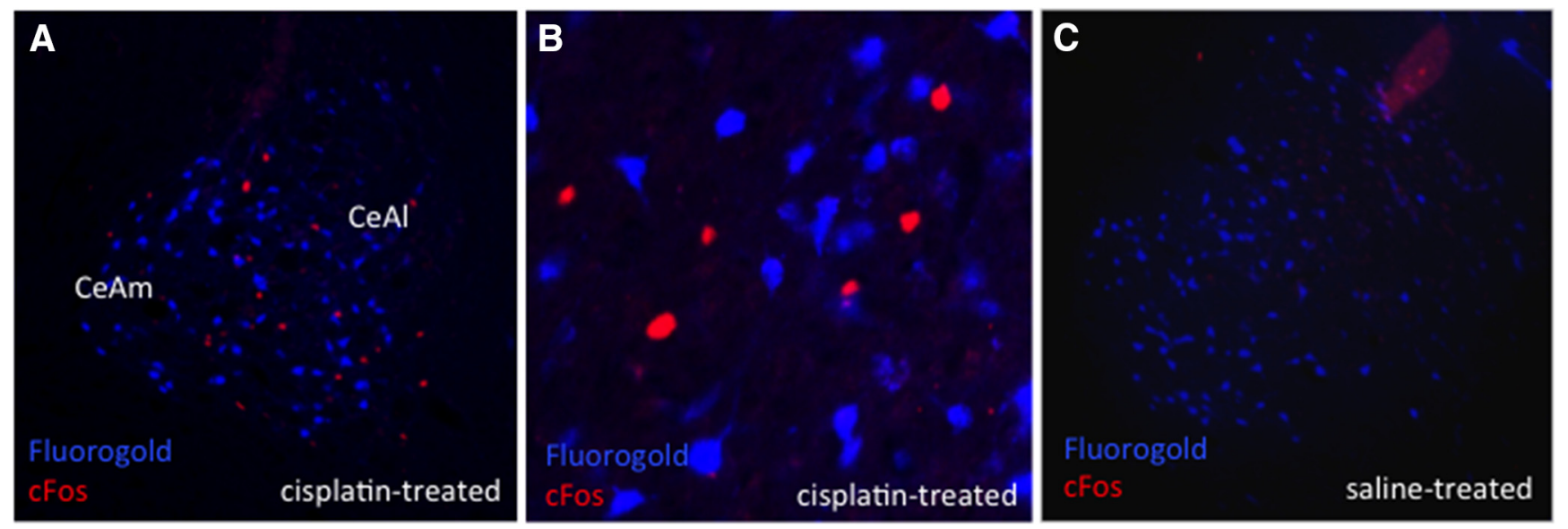

Figure 3. CeA cisplatin-activated neurons do not project directly to the IPBN. Blue immunofluorescence represents FG-expressing neurons and red immunofluorescence represents cisplatininduced cFos-expressing neurons. $\boldsymbol{A}$, Representative CeA image from an IPBN FG and intraperitoneal cisplatin-treated animal. $\boldsymbol{B}$, Representative $20 \times$ CeA image from an IPBN FG- and intraperitoneal cisplatin-treated animal. C, Representative CeA image from an IPBN FG- and intraperitoneal saline-treated animal. $n=5$ cisplatin-treated, $n=5$ saline-treated. CeAl, Lateral part of CeA; CeAm, medial part of CeA.

Table 1. Summary of all cFos, FG, and CGRP cell counts for all immunofluorescence experiments

\begin{tabular}{|c|c|c|c|c|c|c|c|c|c|c|c|c|c|c|c|}
\hline $\begin{array}{l}\text { Site } \\
\text { analyzed }\end{array}$ & $\begin{array}{l}\text { FG } \\
\text { injected in: }\end{array}$ & Injection & $n$ & $\begin{array}{l}\text { Cisplatin- } \\
\text { induced cFos }\end{array}$ & SEM & Fluorogold & SEM & CGRP & SEM & $\begin{array}{l}\text { cFos }+ \\
\text { FG }\end{array}$ & SEM & $\begin{array}{l}\text { cFos }+ \\
\text { CGRP }\end{array}$ & SEM & $\begin{array}{l}\text { CFos + } \\
\text { FG + CGRP }\end{array}$ & SEM \\
\hline \multicolumn{16}{|l|}{ DVC } \\
\hline$A P$ & IPBN & Cisplatin & 4 & 11.8 & 1.0 & 30.2 & 1.3 & \multicolumn{2}{|c|}{ Fibers only } & 9.6 & 0.5 & $\mathrm{~N} / \mathrm{A}$ & & $\mathrm{N} / \mathrm{A}$ & \\
\hline \multirow[t]{2}{*}{ NTS } & \multirow[t]{2}{*}{ IPBN } & Cisplatin & 4 & 26.6 & 1.2 & 130.6 & 2.2 & \multicolumn{2}{|c|}{ Fibers only } & 21.5 & 0.9 & $N / A$ & & $\mathrm{~N} / \mathrm{A}$ & \\
\hline & & Saline & 3 & 0 & 0 & 136.2 & 3.4 & \multicolumn{2}{|c|}{ Fibers only } & 0 & 0 & $\mathrm{~N} / \mathrm{A}$ & & $\mathrm{N} / \mathrm{A}$ & \\
\hline CeA & IPBN & Cisplatin & 5 & 26.5 & 1.8 & 158 & 5.4 & \multicolumn{2}{|c|}{$\mathrm{N} / \mathrm{A}$} & 0 & 0 & $\mathrm{~N} / \mathrm{A}$ & & $\mathrm{N} / \mathrm{A}$ & \\
\hline IPBN & CeA & Saline & 4 & 0.08 & 0.08 & 126 & 2.3 & 42.9 & 3 & 0 & 0 & 0 & 0 & 0 & 0 \\
\hline \multicolumn{16}{|l|}{ DVC } \\
\hline \multirow[t]{2}{*}{ AP } & \multirow[t]{2}{*}{ CeA } & Cisplatin & 3 & 12.7 & 3.8 & 0.78 & 0.19 & \multicolumn{2}{|c|}{ Fibers only } & 0 & 0 & $\mathrm{~N} / \mathrm{A}$ & & $\mathrm{N} / \mathrm{A}$ & \\
\hline & & Saline & 4 & 0.42 & 0.08 & 0.75 & 0.34 & \multicolumn{2}{|c|}{ Fibers only } & 0 & 0 & $\mathrm{~N} / \mathrm{A}$ & & $\mathrm{N} / \mathrm{A}$ & \\
\hline \multirow[t]{2}{*}{ NTS } & \multirow[t]{2}{*}{ CeA } & Cisplatin & 3 & 27 & 7.6 & 13.4 & 1.5 & \multicolumn{2}{|c|}{ Fibers only } & 0 & 0 & $\mathrm{~N} / \mathrm{A}$ & & $\mathrm{N} / \mathrm{A}$ & \\
\hline & & Saline & 4 & 0.4 & 0.09 & 12.3 & 0.87 & \multicolumn{2}{|c|}{ Fibers only } & 0 & 0 & $\mathrm{~N} / \mathrm{A}$ & & $\mathrm{N} / \mathrm{A}$ & \\
\hline
\end{tabular}

Numbers represent average cell counts and SEMs per $35 \mu \mathrm{m}$ brain section.

N/A, Not applicable.

Table 2. Summary of colocalization counts for all immunofluorescence experiments

\begin{tabular}{|c|c|c|c|c|c|c|c|c|c|}
\hline Site analyzed & FG injected in: & Injection & $n$ & $\%$ cFos w/FG & SEM & $\%$ cFos w/CGRP & SEM & \% cFos w/FG + CGRP & SEM \\
\hline \multicolumn{10}{|l|}{ DVC } \\
\hline \multirow[t]{2}{*}{ AP } & IPBN & Cisplatin & 4 & 82.3 & 2.9 & $\mathrm{~N} / \mathrm{A}$ & & N/A & \\
\hline & & Saline & 3 & 0 & 0 & $\mathrm{~N} / \mathrm{A}$ & & $\mathrm{N} / \mathrm{A}$ & \\
\hline \multirow[t]{2}{*}{ NTS } & IPBN & Cisplatin & 4 & 81.3 & 4.4 & $\mathrm{~N} / \mathrm{A}$ & & $\mathrm{N} / \mathrm{A}$ & \\
\hline & & Saline & 3 & 0 & 0 & $\mathrm{~N} / \mathrm{A}$ & & N/A & \\
\hline \multirow[t]{2}{*}{ CeA } & IPBN & Cisplatin & 5 & 0 & 0 & $\mathrm{~N} / \mathrm{A}$ & & $\mathrm{N} / \mathrm{A}$ & \\
\hline & & Saline & 5 & 0 & 0 & $\mathrm{~N} / \mathrm{A}$ & & $N / A$ & \\
\hline \multirow[t]{2}{*}{ IPBN } & CeA & Cisplatin & 5 & 66.5 & 8.3 & 91.9 & 0.34 & 57.4 & 6.8 \\
\hline & & Saline & 4 & 0 & 0 & 0 & 0 & 0 & 0 \\
\hline \multicolumn{10}{|l|}{ DVC } \\
\hline \multirow[t]{2}{*}{ AP } & CeA & Cisplatin & 3 & 0 & 0 & $\mathrm{~N} / \mathrm{A}$ & & $N / A$ & \\
\hline & & Saline & 4 & 0 & 0 & $\mathrm{~N} / \mathrm{A}$ & & $\mathrm{N} / \mathrm{A}$ & \\
\hline \multirow[t]{2}{*}{ NTS } & CeA & Cisplatin & 3 & 0 & 0 & $\mathrm{~N} / \mathrm{A}$ & & $\mathrm{N} / \mathrm{A}$ & \\
\hline & & Saline & 4 & 0 & 0 & $\mathrm{~N} / \mathrm{A}$ & & $\mathrm{N} / \mathrm{A}$ & \\
\hline
\end{tabular}

Numbers represent percentage of cFos cells expressing FG and/or CGRP and SEMs where appropriate.

N/A, Not applicable.

tion in the AP and NTS of cisplatin-treated rats, respectively (Fig. $5 F)$ and $0.42 \pm 0.08$ and $0.4 \pm 0.09$ cFos-expressing neurons in the AP and NTS of saline-treated rats, respectively (Fig. 5C). There were very few FG neurons in the AP: $0.78 \pm 0.19$ cisplatin- treated (Fig. 5D) and $0.75 \pm 0.34$ saline-treated (Fig. 5C) and $13.4 \pm 1.5$ and $12.3 \pm 0.87$ NTS FG-expressing neurons in cisplatin-treated (Fig. 5D) versus saline-treated (Fig. 5C) animals, respectively ( $p=n s$ ). Quantification of CGRP neurons 

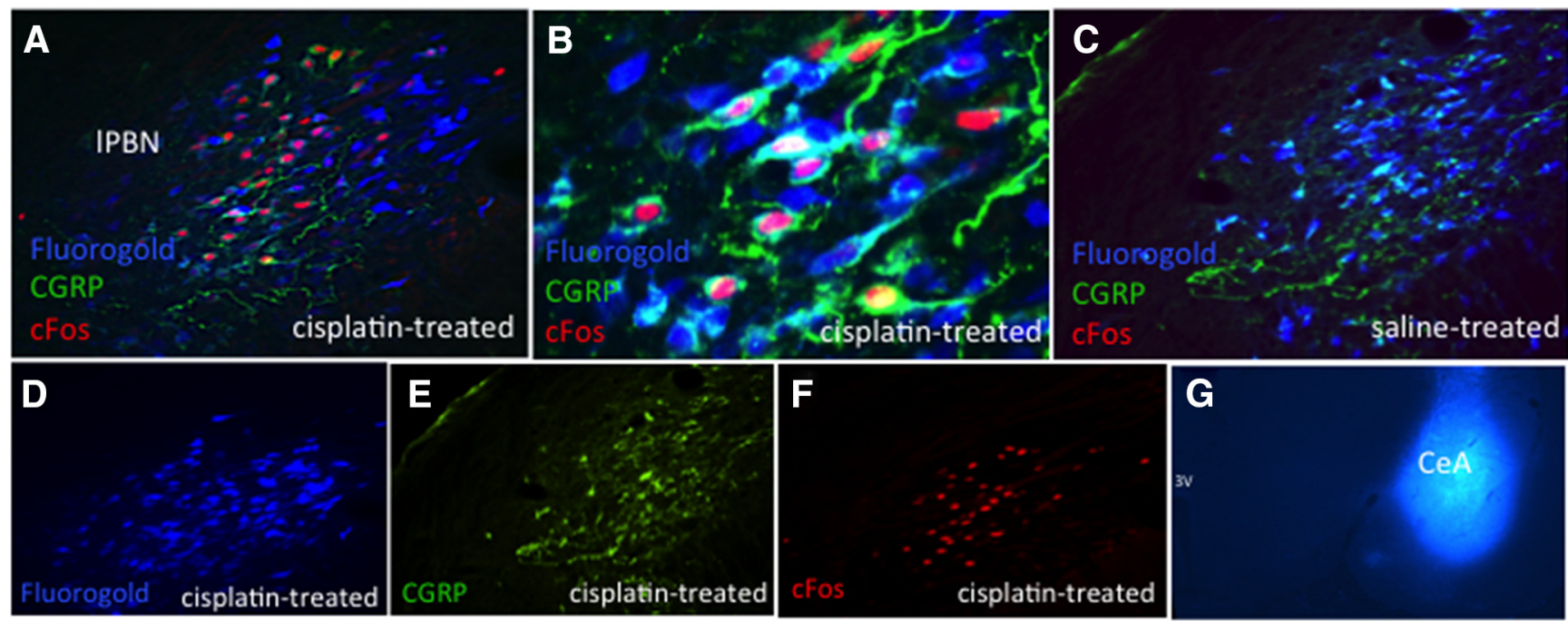

Figure 4. IPBN cisplatin-activated CGRP/glutamate neurons project directly to the ipsilateral CeA. Blue immunofluorescence represents FG-expressing neurons, red immunofluorescence represents cisplatin-induced cFos-expressing neurons, green immunofluorescence represents (GRP-expressing neurons. $A, D, E$, $F$, Representative IPBN images from a CeA FG- and intraperitoneal cisplatin-treated animal. $\boldsymbol{B}$, Representative $20 \times$ IPBN image from a CeA FG- and intraperitoneal cisplatin-treated animal, $\boldsymbol{C}$, Representative IPBN image from a CeA FG- and intraperitoneal saline-treated animal. G, Representative CeA FG injection. $n=5$ cisplatin-treated, $n=4$ saline-treated.

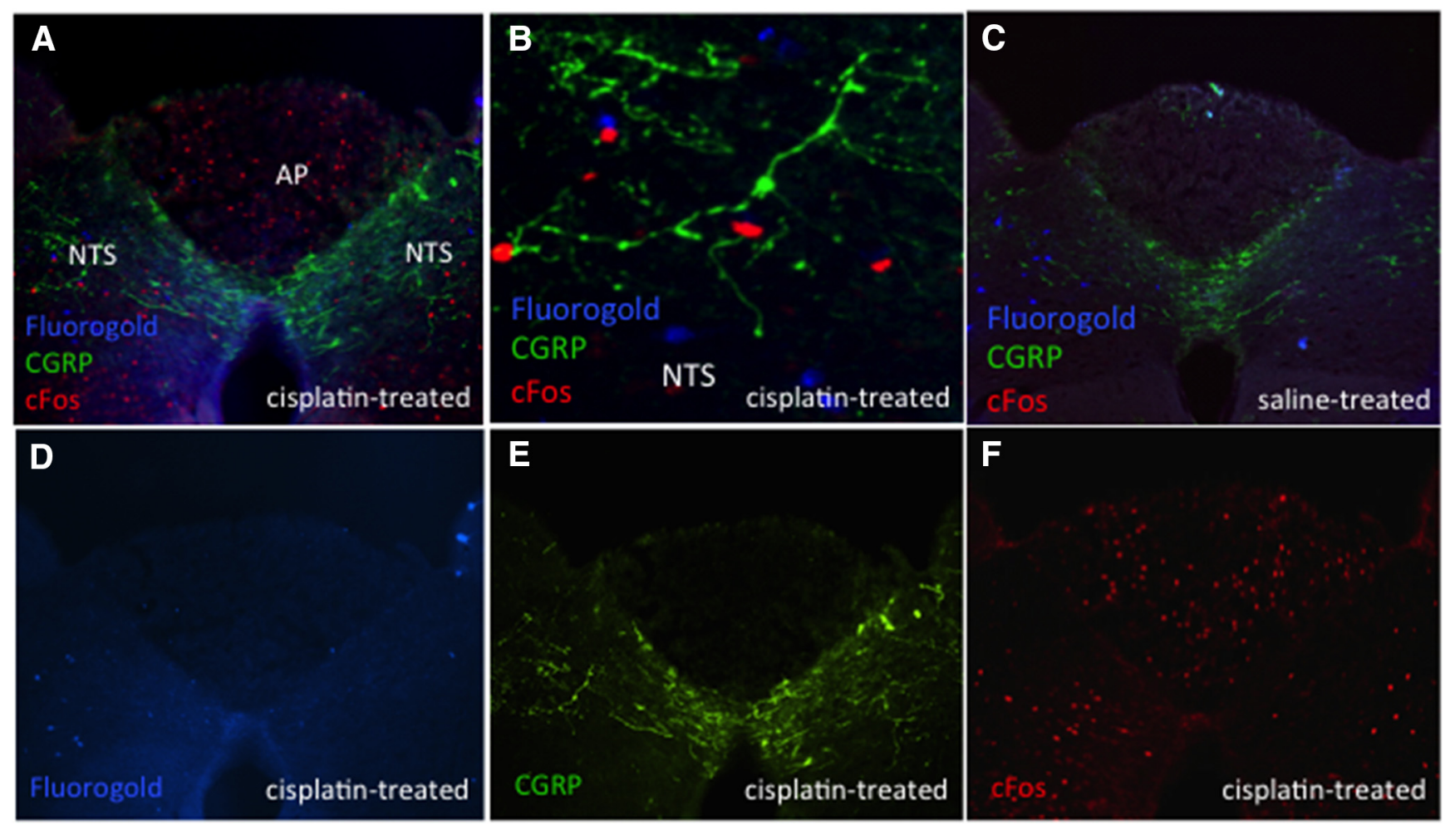

Figure 5. DVC cisplatin-activated neurons do not project directly to the CeA. Blue immunofluorescence represents FG-expressing neurons, red immunofluorescence represents cisplatin-induced CFos-expressing neurons, green immunofluorescence represents CGRP-expressing neurons. $\boldsymbol{A}, \boldsymbol{D}, \boldsymbol{E}, \boldsymbol{F}$, Representative DVC image from a CeA FG- and intraperitoneal cisplatin-treated animal. $\boldsymbol{B}$, Representative $20 \times$ NTS image from a CeA FG- and intraperitoneal cisplatin-treated animal. $\boldsymbol{C}$, Representative DVC image from a CeA FG- and intraperitoneal saline-treated animal. $n=3$ cisplatin-treated, $n=4$ saline-treated.

was limited by an abundance of fiber-like staining patterns with little cell body staining (Fig. $5 E$ ). Nonetheless, in qualitative terms (and as depicted in Fig. 5A,B), near complete segregation of cFos positive neurons in the DVC with CGRP fiber staining or FG staining was observed, showing that, in contrast to the IPBN, cisplatin-induced cFos in the DVC did not co-occur in CGRP-expressing neurons or in neurons projecting to the CeA.
A summary of cFos and FG cell counts for each brain region is provided in Table 1 and a summary of the colocalization between cFos-, FG-, and CGRP-expressing neurons is provided in Table 2.

Experiment 3: Cisplatin increases CeA AMPA and NMDA receptor subunit gene expression

In CeA micropunches taken $6 \mathrm{~h}$ after injection of cisplatin or saline, relative gene expressions for the NMDA receptor subunits 
NR2A $(1.46 \pm 0.15$ cisplatin vs $1.01 \pm$ 0.07 saline $)$ and NR2B ( $1.65 \pm 0.16$ cisplatin vs $1.01 \pm 0.05$ saline) were significantly increased with cisplatin treatment (Fig. $6 A$, all $p<0.05$ ). There was a nonsignificant trend toward an increase in the AMPA receptor subunit GluA2 after cisplatin treatment $(2.03 \pm 0.16$ cisplatin vs $1.05 \pm 0.17$ saline, $p=0.077)$. There were no differences in CeA GluA1 expression $(1.17 \pm 0.11$ cisplatin vs $1.02 \pm 0.11$ saline) nor NR1 expression ( $1.08 \pm 0.08$ cisplatin vs $1.01 \pm 0.07$ saline) in cisplatinversus saline-treated rats (all $p=\mathrm{ns}$ ).

In CeA micropunches taken $24 \mathrm{~h}$ after injection of cisplatin or saline, relative gene expressions for the AMPA receptor subunits GluA1 $(5.24 \pm 1.0$ cisplatin vs $1.13 \pm 0.24$ saline $)$ and GluA2 $(12.4 \pm 2.2$ cisplatin vs $1.1 \pm 0.23$ saline) and the NMDA receptor subunits NR2A (6.59 \pm 1.48 cisplatin vs $1.01 \pm 0.10$ saline) and NR2B (7.96 \pm 1.98 cisplatin vs $1.01 \pm$ 0.10 saline) were significantly increased with cisplatin treatment (Fig. $6 B$, all $p<$ 0.01). There was no difference in CeA NR1 expression in cisplatin- versus salinetreated rats $(1.18 \pm 0.09$ cisplatin vs $1.05 \pm 0.15$ saline, $p=\mathrm{ns}$ ).

\section{Experiment 4: Intra-CeA}

AMPA/kainate receptor blockade attenuates cisplatin-induced pica Intra-CeA AMPA/kainate receptor blockade by CNQX resulted in a significant intraperitoneal drug $\times$ intra-CeA drug treatment interaction at all time points tested (Fig. 7C, all $F_{(1,21)} \geq 3.60 ; p<0.05$ ). Post hoc analyses revealed a significant attenuation of cisplatininduced pica with CeA CNQX pretreatment at all time points tested (vehicle/cisplatin vs CNQX/cisplatin, all $p<0.05$ ).

A significant main effect for cisplatin was observed on food and water intake, as well as body weight loss, at all time points measured (all $F_{(1,21)} \geq 13.22 ; p<0.05$ ), showing comparable reductions in food intake (Fig. $7 A$ ), water intake (Fig. $7 D$ ), and body weight loss (Fig. $7 B$ ) in all groups receiving cisplatin injection regardless of intra-CeA injection treatment (CNQX vs vehicle).

Experiment 5: Intra-CeA NMDA receptor blockade attenuates cisplatin-induced pica, anorexia, and body weight loss

As shown in Figure 8, intra-CeA NMDA receptor blockade showed a significant intraperitoneal drug $\times$ intra-CeA drug treatment interaction on kaolin intake (Fig. $8 C$, all $F_{(1,23)} \geq 18.60$; $p<0.05$ ), food intake (Fig. $8 A$, all $F_{(1,23)} \geq 6.86 ; p<0.05$ ), and body weight loss (Fig. $8 C$, all $F_{(1,23)} \geq 3.60 ; p<0.05$ ) at all time points tested. Post hoc analyses revealed a significant attenuation of cisplatin-induced pica, food intake, and body weight loss with MK-801 pretreatment at all time points tested (vehicle/cisplatin vs MK-801/cisplatin, all $p<0.05)$.

A main effect of intraperitoneal drug treatment was shown for water intake (Fig. $8 D$, all $F_{(1,23)} \geq 30.78 ; p<0.05$ ), with cisplatin treatment similarly reducing water intake in all cisplatin-treated rats.

\section{Discussion}

Although cisplatin chemotherapy is a widely used treatment for cancer, the neurotransmitters and neural circuits mediating its energy balance-compromising side effects remain unknown. Recent data highlight the DVC, $\mathrm{PBN}$, and CeA as potential brain sites mediating cisplatin-induced malaise and energy balance dysregulation (De Jonghe and Horn, 2009; Holland et al., 2014). Here, immunohistochemical studies show that a population of cisplatin-activated DVC neurons projects to the IPBN and that a population of cisplatinactivated IPBN CGRP (a marker for glutamatergic neurons in the IPBN; Carter et al., 2013) neurons projects to the CeA, outlining a neuroanatomical circuit activated by cisplatin. Cisplatin treatment increased gene expressions of CeA AMPA and NMDA receptor subunits, suggesting that CeA glutamate receptor signaling mediates cisplatin side effects. Furthermore, behavioral/pharmacological data show that CeA AMPA/kainate receptor blockade attenuates cisplatin-induced pica (a proxy for nausea/malaise) and CeA NMDA receptor blockade attenuates cisplatin-induced pica, anorexia, and body weight loss in rats. Together, these data highlight a novel CGRP/glutamatergic 


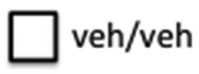

A

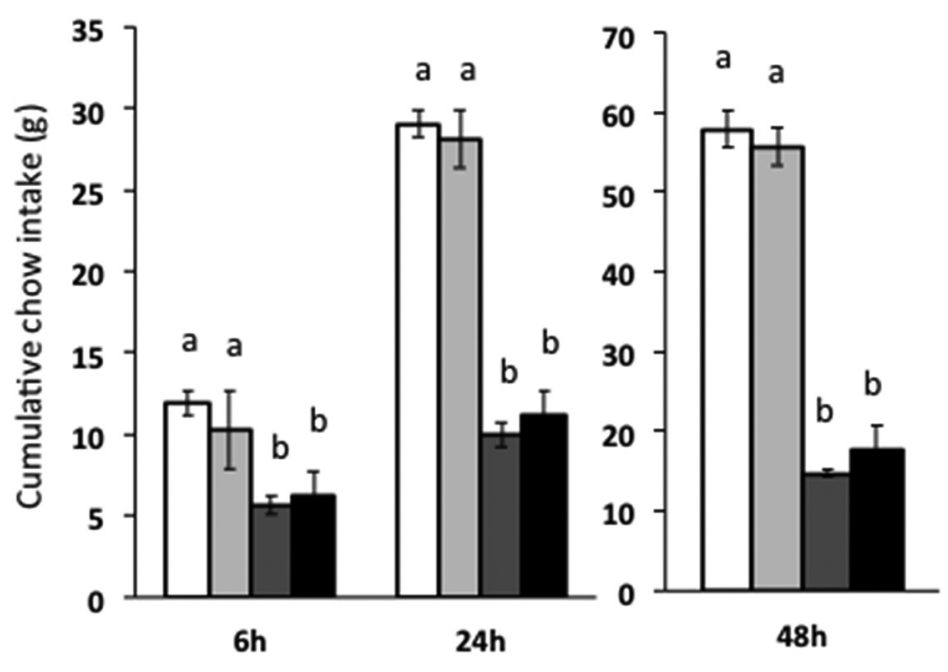

CNQX/veh

B veh/cisplatin
CNQX/cisplatin 24h

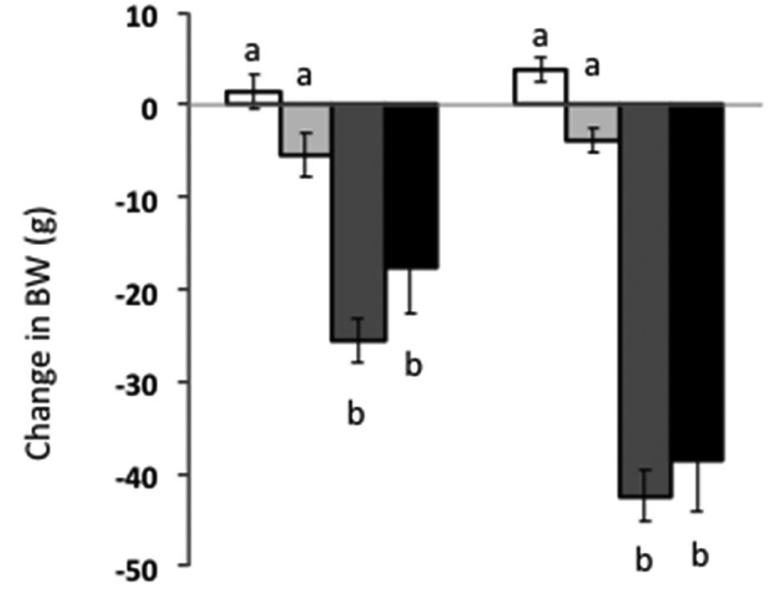

C

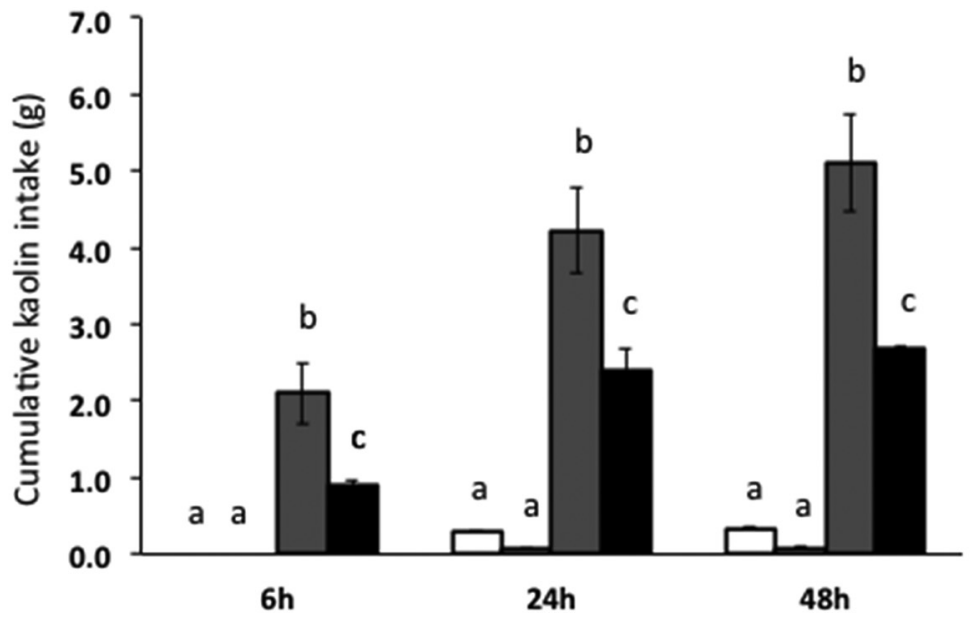

D

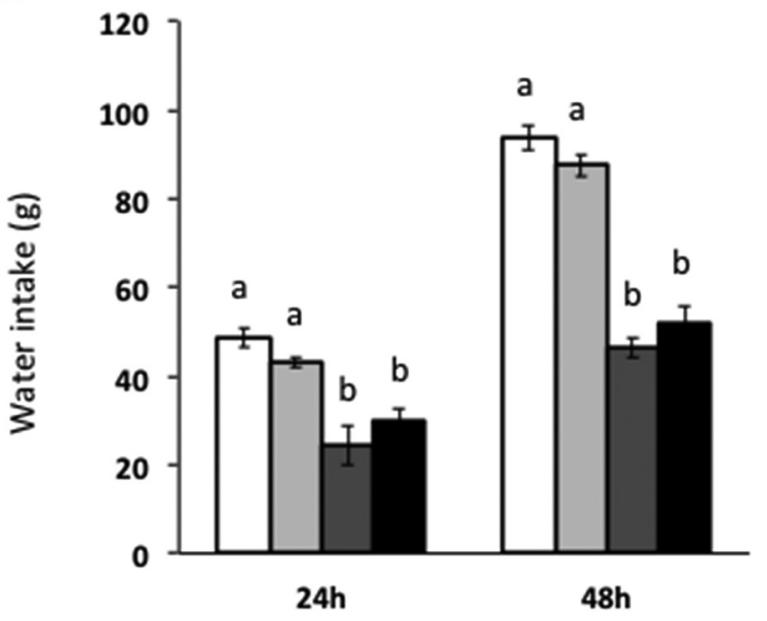

Figure 7. CeA AMPA/kainate receptor blockade attenuated cisplatin-induced pica (as measured by kaolin intake, a proxy for nausea/malaise). The selective AMPA/kainate receptor antagonist CNQX significantly attenuated cisplatin-induced kaolin intake $(\boldsymbol{C})$ and had no effect on cisplatin-induced reduction in chow intake $(\boldsymbol{A})$, reduction in body weight $(\boldsymbol{B})$, or reduction in water intake $(\boldsymbol{D})$. Data are expressed as mean $\pm \mathrm{SEM}, n=11$. Different letters denote significant differences between treatment groups in post hoc comparisons within each time point ( $p<0.05$ ).

mechanism through which cisplatin-induced malaise and energy balance dysregulation are mediated.

Previous studies determined that systemic cisplatin activates DVC, $\mathrm{PBN}$, and CeA neurons in vomiting and nonvomiting animals (Horn et al., 2007; De Jonghe and Horn, 2009; Holland et al., 2014). Here, the connectivity between these distinct nuclei was examined. Neuroanatomical data indicate that most $(>80 \%)$ cisplatin-activated DVC neurons project directly to the $1 \mathrm{PBN}$. This result is not surprising given that there is a robust projection from the DVC to the PBN (Norgren, 1978); however, the data are crucial in supporting a role for the IPBN as a secondary relay site of anorectic and/or nauseogenic effects that manifest after cisplatin treatment. Here, to identify a neurochemical phenotype for cisplatinactivated NTS-to-lPBN neurons, we costained for CGRP based on data indicating that CGRP-expressing neurons are critical for anorexia and behavioral malaise (Carter et al., 2013). Fibrous CGRP immunoreactivity was found through- out the NTS, with virtually no colocalization with cisplatininduced cFos. There are a variety of potential phenotypes for cisplatin-activated DVC neurons. These neurons may be glutamatergic, given that glutamatergic signaling from the NTS to the PBN can lead to profound anorexia and malaise (Wu et al., 2012). If the cisplatin-activated DVC neurons are glutamatergic, then they may also coexpress glucagon-like peptide-1 (GLP-1) because virtually all hindbrain GLP-1-producing neurons coexpress glutamate (Zheng et al., 2014). This possibility raises the hypothesis that the GLP-1 system, which is involved in nausea/vomiting in humans and animals (Buse et al., 2009; Kanoski et al., 2012; Chan et al., 2013), is also involved in mediating cisplatin-induced side effects. This hypothesis is bolstered by data showing that $\sim 70 \%$ of NTS GLP1 -producing neurons innervate CGRP neurons in the IPBN (Richard et al., 2014). Finally, DVC cisplatin-activated neurons could be serotonergic given the well established role of serotonin in malaise and the fact that serotonin neurons in the 


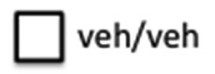

$\square$ MK-801/veh veh/cisplatin
MK-801/cisplatin

B

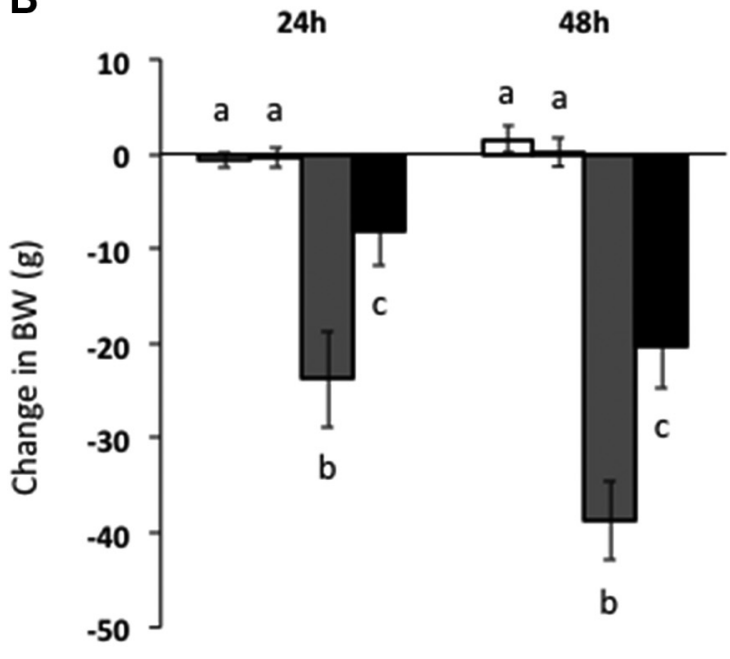

C

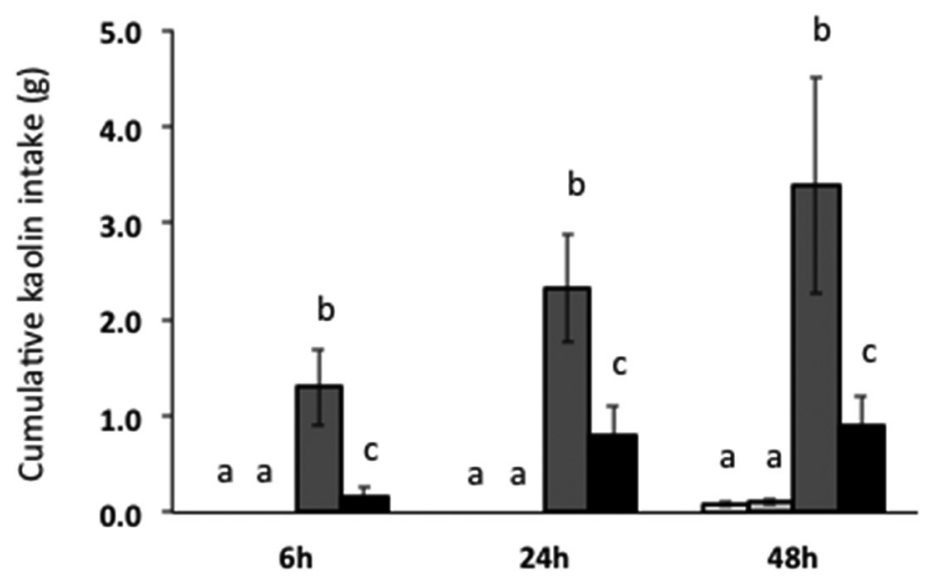

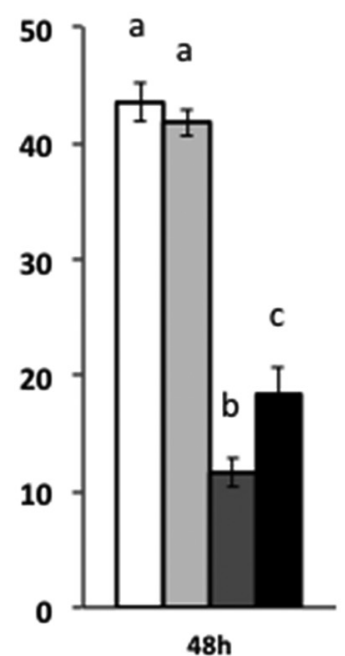

D

$48 \mathrm{~h}$

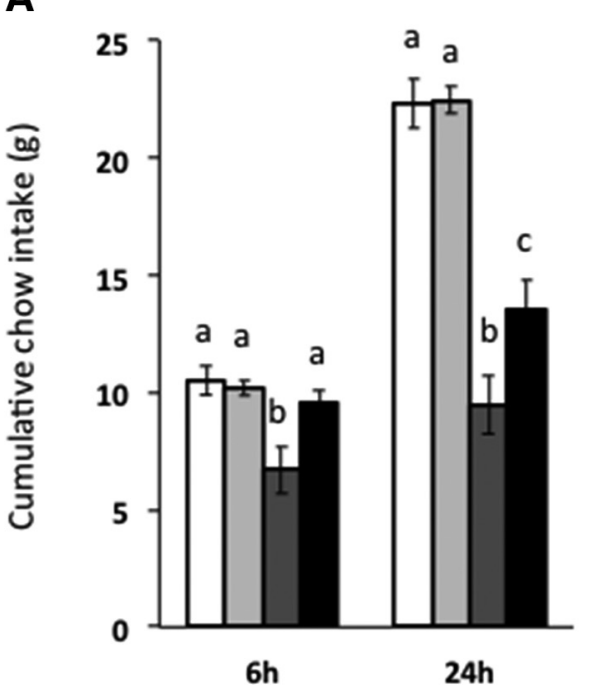

6h

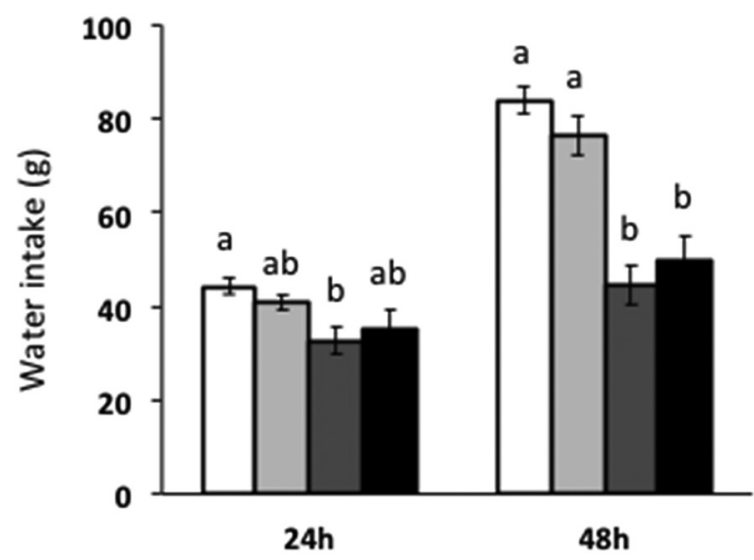

Figure 8. CeA NMDA receptor blockade attenuated cisplatin-induced anorexia, body weight loss, and pica (as measured by kaolin intake, a proxy for nausea/malaise). The selective NMDA receptor antagonist MK-801 significantly attenuated cisplatin-induced reduction in chow intake $(\boldsymbol{A})$, reduction in body weight $(\boldsymbol{B})$, and kaolin intake $(\boldsymbol{C})$ with no effect on cisplatin-induced reduction in water intake $(\boldsymbol{D})$. Data are expressed as mean $\pm \mathrm{SEM}, n=12$. Different letters denote significant differences between treatment groups in post hoc comparisons within each time point $(p<$ 0.05).

AP project directly to the PBN (Lança and van der Kooy, 1985).

Critical to our studies are recent data demonstrating that IPBN-to-CeA CGRP/glutamate neurons are activated by noxious stimuli to reduce food intake (Carter et al., 2013). Because neurons in the IPBN and CeA are stimulated by cisplatin treatment (Horn et al., 2007), we hypothesized that cisplatin-induced energy balance dysregulation may be mediated by these CeAprojecting $\mathrm{PBN}$ CGRP/glutamate neurons. Immunohistochemical studies revealed that nearly all $(>90 \%)$ of 1 PBN cisplatin-activated neurons express CGRP and 57\% of cisplatinactivated neurons express CGRP and project to the CeA. Importantly, these IPBN CGRP neurons coexpress glutamate and glutamate receptor blockade in the CeA abolishes postsynaptic electrophysiological effects of IPBN CGRP neural stimulation (Carter et al., 2013). Our results also identify a small number of IPBN cisplatin-activated neurons that do not express CGRP or project to the CeA. It is possible that some cisplatin-activated IPBN neurons project to the bed nucleus of the stria terminalis (BNST) given that the $1 \mathrm{PBN}$ projects to the BNST (Norgren, 1976; Tokita et al., 2009) and cisplatin induces cFos immunoreactivity in this region (Horn et al., 2007).

We showed previously that glutamate receptor subunits in several central sites are upregulated after cisplatin treatment in mice (Holland et al., 2014). These data, together with our immunohistochemical results, suggest that glutamate signaling in the CeA may be involved mediating cisplatin side effects. Here, gene expression data show that CeA AMPA (GluA1 and GluA2) and NMDA (NR2A and NR2B) receptor subunit levels are robustly increased 6 and/or $24 \mathrm{~h}$ after cisplatin treatment. Given that GluA1, GluA2, NR2A, and NR2B have glutamate-binding domains (Mayer, 2005), the current data fit nicely with a study showing that a peripherally administered noxious stimulus (i.e., lithium chloride) increases amygdala glutamate release (Miranda 
et al., 2002) and raise the hypothesis that a similar mechanism may mediate cisplatin-induced malaise. That we report no change in NR1 gene expression in cisplatin- versus saline-treated rats is not necessarily surprising given that the NR1 subunit lacks a glutamate-binding region and instead binds other ligands such as glycine (Furukawa and Gouaux, 2003). Furthermore, the concept that a noxious stimulus upregulates specific glutamate receptor subunits is supported by existing literature. Specifically, upregulation of NR2B subunits in the IPBN contributes directly to the anorexia after AgRP neuron ablation (Wu et al., 2013) and NR2B is selectively upregulated in a variety of central sites in response to central streptozotocin (Rai et al., 2013). Determining the functional significance of each AMPA and NMDA receptor subunit that is affected by cisplatin treatment is a compelling topic for future investigation.

To determine whether CeA glutamate receptor signaling is required for the expression of cisplatin-induced side effects, rats were treated with an AMPA/kainate or NMDA receptor antagonist before cisplatin administration. Behavioral results showed clearly that CeA AMPA/kainate receptor blockade attenuated cisplatin-induced pica, whereas CeA NMDA receptor blockade attenuated cisplatin-induced pica, anorexia, and reduction in body weight. In these behavioral studies, the percentage of CeA AMPA and NMDA receptors that were blocked by CNQX and MK-801, respectively, is unclear. An incomplete blockade of CeA AMPA and NMDA receptors may in part explain the partial attenuation of cisplatin-induced side effects by these intra-CeA treatments. In addition, the differential findings with $\mathrm{CeA}$ AMPA/kainate versus NMDA receptor antagonism are intriguing. Our results suggest specific mediation of cisplatin-induced pica via AMPA/kainate receptors in the CeA, whereas NMDA receptors are involved in both the malaise and anorectic effects of cisplatin. There are a few potential explanations for these differential results. AMPA- and NMDA-type receptors can be composed of a variety of subunits and the subunit composition can profoundly affect the molecular properties of the receptor (Schoepfer et al., 1994). In addition, AMPA-type receptors are thought to mediate fast excitatory transmission, whereas NMDA-type receptor activation leads to a longer depolarization and synaptic plasticity (Traynelis et al., 2010). The divergent kinetic properties of the receptors invariably lead to unique signaling pathways and subsequent effects on the regulation of transcription/translation (Traynelis et al., 2010). Therefore, although purely speculative at this stage, a divergence in receptor kinetics and secondary messenger/intracellular signaling pathways for AMPA/kainate versus NMDA receptors in CeA neurons could explain the current results.

In this context, identifying intracellular signals mediating the interaction between cisplatin and CeA glutamate signaling provides a interesting direction for future research. A study from Cai et al. (2014) identified a population of protein kinase C- $\delta^{+}$ $\left(\mathrm{PKC}-\delta^{+}\right.$) neurons in the CeA that are activated by anorexigenic and emetic agents such as cholecystokinin, lithium chloride, and lipopolysaccharide and receive excitatory inputs from the IPBN (Cai et al., 2014). Therefore, it is possible that cisplatin treatment activates these CeA PKC- $\delta^{+}$neurons to exert its effects. The investigators suggested that the anorexic effects of PKC- $\delta^{+}$neuron stimulation are mediated by local circuits in the amygdala. These effects, as well as projections from CeA to other sites that receive CeA afferents (e.g., BNST, insular cortex), should be investigated in the context of mediation of cisplatin-induced anorexia and malaise.
In addition to pica (an innate behavior used to measure malaise), the conditioned taste avoidance/aversion (CTA) paradigm is commonly used to assess malaise by measuring an association between a novel taste and visceral illness. The classical literature shows that lesions of the CeA do not interfere with lithium chloride CTA acquisition (Hatfield et al., 1996; Reilly and Bornovalova, 2005). Although these studies suggest that the CeA is not necessary for CTA, a recent study from Carter et al. (2015) elegantly showed that the projection from IPBN CGRP neurons to the CeA is both necessary and sufficient for acquisition of a CTA. Together with our data, these studies demonstrate that CGRP IPBN-to-CeA neurons are important, not only for CTA acquisition, but also for innate pica behavior after visceral malaise.

Collectively, these data demonstrate that glutamate receptor signaling in the CeA is necessary for maximal expression of cisplatin-induced nausea/malaise, anorexia, and body weight loss. In addition, the present studies combine neuroanatomical tracing and IHC to outline and phenotype a neural circuit connecting regions of hindbrain and forebrain activated by cisplatin chemotherapy. Together, these data help to characterize the neural circuits and neurotransmitters mediating cisplatin-induced malaise and energy balance dysregulation, which will ultimately provide the opportunity for the development of successful, well tolerated cancer chemotherapies.

\section{References}

Alhadeff AL, Baird JP, Swick JC, Hayes MR, Grill HJ (2014) Glucagon-like Peptide-1 receptor signaling in the lateral parabrachial nucleus contributes to the control of food intake and motivation to feed. Neuropsychopharmacology 39:2233-2243. Medline

Andrews PL, Horn CC (2006) Signals for nausea and emesis: Implications for models of upper gastrointestinal diseases. Auton Neurosci 125:100 115. CrossRef Medline

Andrews PL, Sanger GJ (2014) Nausea and the quest for the perfect antiemetic. Eur J Pharmacol 722:108-121. CrossRef Medline

Bence KK, Delibegovic M, Xue B, Gorgun CZ, Hotamisligil GS, Neel BG, Kahn BB (2006) Neuronal PTP1B regulates body weight, adiposity and leptin action. Nat Med 12:917-924. CrossRef Medline

Buse JB, Rosenstock J, Sesti G, Schmidt WE, Montanya E, Brett JH, Zychma M, Blonde L; LEAD-6 Study Group (2009) Liraglutide once a day versus exenatide twice a day for type 2 diabetes: a 26-week randomised, parallelgroup, multinational, open-label trial (LEAD-6). Lancet 374:39-47. CrossRef Medline

Cai H, Haubensak W, Anthony TE, Anderson DJ (2014) Central amygdala PKC-delta $(+)$ neurons mediate the influence of multiple anorexigenic signals. Nat Neurosci 17:1240-1248. CrossRef Medline

Carter ME, Soden ME, Zweifel LS, Palmiter RD (2013) Genetic identification of a neural circuit that suppresses appetite. Nature 503:111-114. CrossRef Medline

Carter ME, Han S, Palmiter RD (2015) Parabrachial calcitonin gene-related peptide neurons mediate conditioned taste aversion. J Neurosci 35:45824586. CrossRef Medline

Chan SW, Lin G, Yew DT, Yeung CK, Rudd JA (2013) Separation of emetic and anorexic responses of exendin-4, a GLP-1 receptor agonist in Suncus murinus (house musk shrew). Neuropharmacology 70:141-147. CrossRef Medline

Covasa M, Ritter RC, Burns GA (2003) Cholinergic neurotransmission participates in increased food intake induced by NMDA receptor blockade. Am J Physiol Regul Integr Comp Physiol 285:R641-R648. CrossRef Medline

De Jonghe BC, Horn CC (2008) Chemotherapy-induced pica and anorexia are reduced by common hepatic branch vagotomy in the rat. Am J Physiol Regul Integr Comp Physiol 294:R756-R765. CrossRef Medline

De Jonghe BC, Horn CC (2009) Chemotherapy agent cisplatin induces $48 \mathrm{~h}$ Fos expression in the brain of a vomiting species, the house musk shrew (Suncus murinus). Am J Physiol Regul Integr Comp Physiol 296:R902R911. CrossRef Medline

Furukawa H, Gouaux E (2003) Mechanisms of activation, inhibition and 
specificity: crystal structures of the NMDA receptor NR1 ligand-binding core. EMBO J 22:2873-2885. CrossRef Medline

Hatfield T, Han JS, Conley M, Gallagher M, Holland P (1996) Neurotoxic lesions of basolateral, but not central, amygdala interfere with Pavlovian second-order conditioning and reinforcer devaluation effects. J Neurosci 16:5256-5265. Medline

Hettes SR, Heyming TW, Stanley BG (2007) Stimulation of lateral hypothalamic kainate receptors selectively elicits feeding behavior. Brain Res 1184:178-185. CrossRef Medline

Holland RA, Leonard JJ, Kensey NA, Hannikainen PA, De Jonghe BC (2014) Cisplatin induces neuronal activation and increases central AMPA and NMDA receptor subunit gene expression in mice. Physiol Behav 136:7985. CrossRef Medline

Horn CC (2009) Brain Fos expression induced by the chemotherapy agent cisplatin in the rat is partially dependent on an intact abdominal vagus. Auton Neurosci 148:76-82. CrossRef Medline

Horn CC, Ciucci M, Chaudhury A (2007) Brain Fos expression during $48 \mathrm{~h}$ after cisplatin treatment: neural pathways for acute and delayed visceral sickness. Auton Neurosci 132:44-51. CrossRef Medline

Kanoski SE, Rupprecht LE, Fortin SM, De Jonghe BC, Hayes MR (2012) The role of nausea in food intake and body weight suppression by peripheral GLP-1 receptor agonists, exendin-4 and liraglutide. Neuropharmacology 62:1916-1927. CrossRef Medline

Lança AJ, van der Kooy D (1985) A serotonin-containing pathway from the area postrema to the parabrachial nucleus in the rat. Neuroscience 14: 1117-1126. CrossRef Medline

Mayer ML (2005) Glutamate receptor ion channels. Curr Opin Neurobiol 15:282-288. CrossRef Medline

Mietlicki-Baase EG, Ortinski PI, Rupprecht LE, Olivos DR, Alhadeff AL, Pierce RC, Hayes MR (2013) The food intake-suppressive effects of glucagon-like peptide-1 receptor signaling in the ventral tegmental area are mediated by AMPA/kainate receptors. Am J Physiol Endocrinol Metab 305:E1367-E1374. CrossRef Medline

Mietlicki-Baase EG, Ortinski PI, Reiner DJ, Sinon CG, McCutcheon JE, Pierce RC, Roitman MF, Hayes MR (2014) Glucagon-like peptide-1 receptor activation in the nucleus accumbens core suppresses feeding by increasing glutamatergic AMPA/kainate signaling. J Neurosci 34:6985-6992. CrossRef Medline

Miranda MI, Ferreira G, Ramirez-Lugo L, Bermudez-Rattoni F (2002) Glutamatergic activity in the amygdala signals visceral input during taste memory formation. Proc Natl Acad Sci U S A 99:11417-11422. CrossRef Medline

Norgren R (1976) Taste pathways to hypothalamus and amygdala. J Comp Neurol 166:17-30. CrossRef Medline
Norgren R (1978) Projections from the nucleus of the solitary tract in the rat. Neuroscience 3:207-218. CrossRef Medline

Percie du Sert N, Rudd JA, Apfel CC, Andrews PL (2011) Cisplatin-induced emesis: systematic review and meta-analysis of the ferret model and the effects of 5-HT(3) receptor antagonists. Cancer Chemother Pharmacol 67:667-686. CrossRef Medline

Rai S, Kamat PK, Nath C, Shukla R (2013) A study on neuroinflammation and NMDA receptor function in STZ (ICV) induced memory impaired rats. J Neuroimmunol 254:1-9. CrossRef Medline

Reilly S, Bornovalova MA (2005) Conditioned taste aversion and amygdala lesions in the rat: a critical review. Neurosci Biobehav Rev 29:1067-1088. CrossRef Medline

Richard JE, Farkas I, Anesten F, Anderberg RH, Dickson SL, Gribble FM, Reimann F, Jansson JO, Liposits Z, Skibicka KP (2014) GLP-1 receptor stimulation of the lateral parabrachial nucleus reduces food intake: neuroanatomical, electrophysiological and behavioral evidence. Endocrinology 155:4356-4367. CrossRef Medline

Schoepfer R, Monyer H, Sommer B, Wisden W, Sprengel R, Kuner T, Lomeli H, Herb A, Köhler M, Burnashev N, et al. (1994) Molecular biology of glutamate receptors. Prog Neurobiol 42:353-357. CrossRef Medline

Tokita K, Inoue T, Boughter JD Jr (2009) Afferent connections of the parabrachial nucleus in C57BL/6 J mice. Neuroscience 161:475-488. CrossRef Medline

Traynelis SF, Wollmuth LP, McBain CJ, Menniti FS, Vance KM, Ogden KK, Hansen KB, Yuan H, Myers SJ, Dingledine R (2010) Glutamate receptor ion channels: structure, regulation, and function. Pharmacol Rev 62:405496. CrossRef Medline

Treece BR, Covasa M, Ritter RC, Burns GA (1998) Delay in meal termination follows blockade of N-methyl-D-aspartate receptors in the dorsal hindbrain. Brain Res 810:34-40. CrossRef Medline

Vezzani A, Serafini R, Stasi MA, Caccia S, Conti I, Tridico RV, Samanin R (1989) Kinetics of MK-801 and its effect on quinolinic acid-induced seizures and neurotoxicity in rats. J Pharmacol Exp Ther 249:278-283. Medline

Von Hoff DD, Schilsky R, Reichert CM, Reddick RL, Rozencweig M, Young RC, Muggia FM (1979) Toxic effects of cis-dichlorodiammineplatinum(II) in man. Cancer Treat Rep 63:1527-1531. Medline

Wu Q, Clark MS, Palmiter RD (2012) Deciphering a neuronal circuit that mediates appetite. Nature 483:594-597. CrossRef Medline

Wu Q, Zheng R, Srisai D, McKnight GS, Palmiter RD (2013) NR2B subunit of the NMDA glutamate receptor regulates appetite in the parabrachial nucleus. Proc Natl Acad Sci U S A 110:14765-14770. CrossRef Medline

Zheng H, Stornetta RL, Agassandian K, Rinaman L (2014) Glutamatergic phenotype of glucagon-like peptide 1 neurons in the caudal nucleus of the solitary tract in rats. Brain Struct Funct. In press. 